\title{
DUKUNGAN KADER KESEHATAN TERHADAP KEMANDIRIAN FISIK PASIEN TUBERKULOSIS PARU
}

\author{
Khoiroh Umah ${ }^{1,}$ Meidiana Dwidiyanti ${ }^{2,}$ Megah Andriany ${ }^{3}$ \\ ${ }^{1}$ Mahasiswa Magister Keperawatan Universitas Diponegoro \\ ${ }^{2}$ Staf Pengajar Departemen Keperawatan Universitas Diponegoro \\ ${ }^{3}$ Staf Pengajar Departemen Keperawatan Universitas Diponegoro \\ Email: Khoirohumah83@gmail.com
}

\begin{abstract}
Self-reliance of TB patients has an effect on the adherence to treatment in the healing process. To achieve self-reliance, patients require supports from the family and community, as well as knowledge and skills to be able to take care of themselves independently. Healthcare cadres are one form of supports that the patients need to maintain self-care capabilities. The purpose of this study was to analyze the effects of health cadres' supports on the physical self-reliance in pulmonary TB patients. This study was a quantitative research with a pretest-posttest quasi-experimental design with the control group. The samples were 44 patients recruited using purposive sampling technique with inclusion and exclusion criteria and were assigned to two groups: intervention group $(n=22)$ and control group $(n=22)$. Instrument used modified healty card owner by Dwidiyanti. The intervention given was in the form of health cadres' supports given for six times in six weeks. A statistical analysis using paired t-test was performed to identify the effects of the intervention on the physical self-reliance in patients with pulmonary tuberculosis. The results showed that the intervention group obtained a p-value of 0.00 and $\alpha$ of 0.05 , where p-value $<\alpha$, or p-value $<0.05$, indicating that there was an effect of health cadres' supports on physical self-reliance in patients with pulmonary TB. Meanwhile, in the control group, a p-value of 0.529 and $\alpha$ of 0.05 were found, where $p$-value $>\alpha$ or $p$-value $>0.05$, indicating that there was no significant difference in the patients' physical self-reliance after given supports from the health cadres. Support interventions of health cadres improved the physical self-reliance in patients with pulmonary TB.
\end{abstract}

Keywords: Support, health cadres, physical self-reliance, pulmonary tuberculosis

Abstrak: Kemandirian pasien TB berpengaruh terhadap kepatuhan berobat dalam proses penyembuhan.Untuk mencapai kemandirian, pasien memerlukan dukungan keluarga dan masyarakat, serta pengetahuan dan skill untuk mampu merawat diri secara mandiri. Kader kesehatan adalah salah satu dukungan yang dibutuhkan untuk mempertahankan kemampuan perawatan mandiri.Tujuan penelitian ini adalah untuk menganalisa pengaruh dukungan kader kesehatan terhadap kemandirian fisik pasien TB paru. jenis penelitian kuantitatif dengan desain quasi eksperimental menggunakan pendekatan pretest-posttest with control group design.Sampel dalam penelitian ini adalah 44 subjek yang dipilih dengan teknik purposive sampling sesuai dengan kriteria inklusi dan eksklusi.Sampel dibagi menjadi 2 kelompok yaitu kelompok intervensi $(n=22)$ dan kelompokkontrol $(n=22)$. Instrumen yang digunakan kartu sehat mandiri milik dwidiyanti yang dimodifikasi. Intervensi berupa dukungan kader kesehatan dilakukan enam kali selama enam minggu.Analisis statistic dilakukan menggunakan uji paired t-test untuk melihat pengaruh intervensi terhadap kemandirian fisik pasien TB paru. Hasil penelitian ini menunjukan bahwa kelompok intervensi mendapatkan $p$-value $=0,00$ dan $\alpha=0,05$, dimana $p$-value $<\alpha$ ataup-value $<0,05$, yang berarti ada pengaruh dukungan kader kesehatan terhadap kemandirian fisik pada pasien 
TB paru. Kelompok kontrol menghasilkan $p$-value $=0,529 \mathrm{dan} \alpha=0,05$, dimana $p$-value $>\alpha$ atau $p$-value $>0,05 y$ ang berarti tidak ada perbedaan yang signifikan pada kemandirian fisik pasien setelah diberikan dukungan oleh kader kesehatan. Intervensi dukungan kader kesehatan dapat meningkatkan kemandirian fisik pada pasien TB paru.

Kata kunci: Dukungan, kaderkesehatan, kemandirianfisik, tuberkulosisparu

\section{PENDAHULUAN}

Indonesia menduduki peringkat kedua bersama dengan Tiongkok. Berdasarkan global report TB tahun 2014 diperkirakan TB paru di Indonesia tahun 2015, berdasarkan survei 2013 naik sebanyak 1 juta kasus baru per tahun (Arif, 2015). Data Kementerian Kesehatan Republik Indonesia menunjukkan bahwa insiden TB paru Basil Tahan Asam (BTA) positif di Indonesia tahun 2014 yaitu 176.677 kasus.(Dinkes Jatim, 2014).Jumlah kasus TB paru di Indonesia masih tinggi juga dikarenakan banyaknya penderita tidak melanjutkan pengobatan sampai benar-benar dinyatakan sembuh oleh dokter. Pasien TB paru yang telah menjalani pengobatan selama 2 bulan, merasa tidak ada gejala TB paru dan merasa kondisinya seperti sediakala, hal ini menyebabkan pasien merasa percaya diri untuk meninggalkan pengobatan (bimantara, 2016).Penyakit TB paruberdampak buruk bagi pasien secara fisik, ekonomi dan psikologis.Kesuksesan pengobatan pasien TB paru terlihat dari kemampuan pasien dalam melakukan perawatan diri secara mandiri. Pasien TB paru yang mandiri akan mempengaruhi kondisi pasien TB paru sendiri baik fisik dan rohaninya, depresi, sakit dan meningkatkan kualitas hidup (Meidiana, 2014).

Pasien TB paru di wilayah Puskesmas Deket Kabupaten Lamongan rata-rata masih belum mandiri memenuhi kebutuhan kegiatan sehari-hari, masih membutuhkan bantuan keluarga. Hasil survei pada wilayah Puskesmas Deket Kabupaten Lamongan pada Desember 2016 menunjukkan pasien TB paru masih sering merasa bosan minum obat TB paru yang diminum tiap hari yang berbentuk besar, pasien jarang makan teratur tiap hari, pasien sering tidak pakai alat pelindung diri berupa masker dalam berkontak dengan orang lain, sering juga buang ludah tidak pada tempatnya, sering batuk tidak menutup mulut, jarang membuka jendela/pintu pada pagi hari, Pasien TB paru ada yang mengambil obat diambilkan keluarganya, pasien ada yang tidak periksa ke tenaga kesehatan jika mengalami keluhan fisik seperti mual, muntah, pusing, telinga berdengung dan pandangan kabur. Tetapi pasien masih bertahan dengan tidak melakukan konsultasi dengan dokter Puskesmas atau tenaga kesehatan untuk penatalaksanaan dari keluhan fisiknya tersebut. Pasien ada yang tidak periksa dahak sesuai dengan anjuran tenaga kesehatan. Pada masalah tersebut diperlukan kemandirian fisik pada pasien TB paru dalam kegiatan seharihari untuk mendapatkan pengobatan yang sesuai dan harapan cepat sembuh.

Upaya yang dilakukan untuk meningkatkan kemandirian dilakukan dengan masyarakat salah satunya melalui keluarga, karena keluarga merupakan anggota keluarga terdekat, sehingga bisa memantaukemandirian pasien TB paru tentang perawatan anggota keluarga yang menderita TB paru. Masyarakat terdekat dalam keluarga TB paru adalah kader 
kesehatanPada peneliti sebelumnya sudah ada yang menyebutkan bahwa terdapat peningkatan kemandirian fisik pada pasien TB paru dengan diberikan intervensi mindfulness. Pasien TB paru setelah diberi efikasi diri dari tidak yakin menjadi yakin, karena pasien yang telah diberikan mindfulness menyadarkan pasien secara penuh tentang dirinya tanpa ada penolakan (Nooratri, 2016).Intervensi ini membutuhkan keahlian tingkat lanjut (advance) yang sulit dilakukan pada kader kesehatan, sehingga dibutuhkan intervensi yang dapat dilakukan oleh kader kesehatan berupa dukungan terhadap kemandirian fisik pada pasien TB paru.Tujuan penelitian ini mengetahui pengaruh intervensi dukungan kader kesehatan terhadap kemandirian fisik pada pasien TB paru di Puskesmas Deket Kabupaten lamongan.

\section{METODE}

Penelitian ini merupakan jenis penelitian kuantitatif dengan desain quasy eksperimental dengan menggunakan pendekatan pretestposttest with control group design. Sampel dalam penelitian ini dibagi duaa kelompok yaitu kelompok intervensi yang diberi intervensi dukungan kader kesehatan dan kelompok kontrol tidak diberi intervensi. Kriteria pemilikan Kelompok kontrol dengan memiliki karakteristik sama dengan kelompok intervensi.
Pengambilan sampel dilakukan dengan teknik purposive sampling dengan kriteria inklusi responden pasien TB paru berusia 19-60 tahun, pasien TB paru tidak meninggalkan wilayah tempat tinggal /rumahnya pada saat penelitian dan pasien TB paru sedang menjalani pengobatan. Sedangkan kriteria eksklusi yaitu pasien TB paru yang diteliti menderita penyakit lain misalnya hipertensi HIV dan DM, pasien TB paru hamil saat pengobatan.

Peneliti menggunakan instrument kuesioner kartu sehat mandiri milik Dwidiyanti yang semua dimodifikasi dan disesuaikan dengan skala guttman pada kemandirian fisik pada pasien TB paru. Dengan mengisi lembar observasi yang berupa pertanyaan yang mengukur kemandirian fisik pasien TB paru, makin tinggi skor yang diperoleh makin tinggi tingkat kemandirian fisik pasien TB paru. Kuisioner berupa pertanyaan untuk menentukan skor kemandirian fisik pasien TB paru. Responden sesuai dengan kriteria inklusi dan eksklusi diambil 44 untuk selanjutnya diikutkan dalam proses penelitian. Intervensi dilakukan selama enam minggu.

\section{HASIL DAN PEMBAHASAN}

Pengambilan data dilakukan pada 19 Juni -22 Juli 2017. Peneliti mendapatkan 46 responden terlibat dalam proses penelitian. Karakteristik responden meliputi usia, jenis kelamin, pendidikan, Pekerjaan. Status dan penghasilan rata- rata.

Tabel 1.1 Homogenitas Responden Kelompok Intervensi (n=22) dan Kelompok Kontrol $(\mathbf{n}=\mathbf{2 2})$

\begin{tabular}{|c|c|c|c|c|c|c|c|}
\hline & Variabel & & $\begin{array}{c}\text { Kelompok } \\
\text { Intervensi } \\
(\mathrm{n}=22)\end{array}$ & & $\begin{array}{c}\text { Kelompok } \\
\text { Kontrol } \\
(n=22)\end{array}$ & & p-value \\
\hline \multirow{3}{*}{1} & & & $\mathrm{n}$ & $\%$ & $\mathrm{n}$ & $\%$ & \\
\hline & Usia & 18-40 tahun & 6 & 27,3 & 8 & 36,4 & 0,216 \\
\hline & & $41-60$ tahun & 16 & 72,7 & 14 & 63,6 & \\
\hline
\end{tabular}




\begin{tabular}{|c|c|c|c|c|c|c|c|}
\hline$\overline{\text { No }}$ & Variabel & & $\begin{array}{c}\text { Kelompok } \\
\text { Intervensi } \\
(n=22)\end{array}$ & & $\begin{array}{c}\text { Kelompok } \\
\text { Kontrol } \\
(\mathrm{n}=22)\end{array}$ & & p-value \\
\hline \multirow[t]{2}{*}{2} & Jenis & Laki-laki & 11 & 50 & 14 & 63,6 & 0,201 \\
\hline & & Perempuan & 11 & 50 & 8 & 36,4 & \\
\hline \multirow[t]{3}{*}{3} & Pendidikan & $\begin{array}{l}\text { Lulusan } \\
\text { SMP/ } \\
\text { sederajat }\end{array}$ & 16 & 72,7 & 18 & 81,8 & 0,16 \\
\hline & & $\begin{array}{l}\text { Lulusan } \\
\text { SMA/ } \\
\text { sederajat }\end{array}$ & 6 & 27,3 & 4 & 18,2 & \\
\hline & & PT & 0 & 0 & 0 & 0 & \\
\hline \multirow[t]{5}{*}{4} & Pekerjaan & Petani & 14 & 63,6 & 12 & 54.5 & 0,514 \\
\hline & & Buruh & 0 & 0 & 1 & 4,5 & \\
\hline & & PNS & 0 & 0 & 0 & 0 & \\
\hline & & Wiraswasta & 5 & 22,7 & 8 & 36,4 & \\
\hline & & Lain-lain & 3 & 0 & 1 & 4,5 & \\
\hline \multirow[t]{3}{*}{5} & Status & Menikah & 19 & 86,4 & 20 & 90,9 & 0,353 \\
\hline & & Tidak & 3 & 13,6 & 2 & 9,1 & \\
\hline & & Menikah & & & & & \\
\hline \multirow[t]{2}{*}{6} & $\begin{array}{l}\text { Penghasila } \\
\text { n rata- rata }\end{array}$ & $>$ Rp & 12 & 54,5 & 11 & 50 & 0,678 \\
\hline & & $\begin{array}{l}<\mathrm{Rp} \\
1.400 .000\end{array}$ & 10 & 45,5 & 11 & 50 & \\
\hline
\end{tabular}

Karakteristik responden meliputi umur, dan intervensi setelah dilakukan uji jenis kelamin, pendidikan, pekerjaan, status pernikahan dan penghasilan ratarata perbulan pada kelompok kontrol homogenitas, hasilnya homogen. Sehingga tidak ada perbedaan karakteristik di dua kelompok tersebut.

Tabel 2 Pengaruh Dukungan Kader Kesehatan terhadap Kemandirian Fisik pada Kelompok intervensi dan Kelompok Kontrol pada tanggal 19 Juni-22 Juli 2017 (N=44)

\begin{tabular}{clcccc}
\hline Variabel & Kelompok & Mean & SD & $\begin{array}{c}\text { Min- } \\
\text { Max }\end{array}$ & $p$-value \\
$\begin{array}{c}\text { Kemandirian } \\
\text { fisik }\end{array}$ & & & & & \\
\hline Intervensi & Pre test & 5,55 & 1,101 & $4-8$ & 0,000 \\
& Post Test & 6,95 & 1,174 & $5-9$ & \\
\hline Kontrol & Pre test & 5,95 & 1,362 & $4-9$ & 0,529 \\
& Post test & 6,14 & 1,283 & $4-9$ & \\
\hline
\end{tabular}

Pemberian dukungan kader kesehatan pada pasien TB paru berdasarkan perhitungan statistik di peroleh rata-rata skor pada kelompok intervensi adalah 5,55 menjadi 6,95 . Terdapat peningkatan yang signifikan 1,4.Dengan menggunakan uji paired $t$ testp-value $\quad=0,00 \quad$ dan $\quad \alpha=0,05$ menunjukkan $p$-value $<\alpha$ atau $p$-value $<$ 0,05 yang berarti ada pengaruh dukungan kader kesehatan terhadap kemandirian fisik pada pasien TB paru.

Berdasarkan penelitian Pratiwi (2012) kemandirian masyarakat dapat dinilai dari beberapa faktor antara lain: 
kemandirian dalam melakukan
pencegahan penyakit TB paru, kemandirian pemeriksaan ulang dahak pasca penyembuhan. Nilai tentang penyakit TB paru di masyarakat dapat membentuk norma subjektif pada masyarakat yang akan mempengaruhi upaya kemandirian masyarakat dalam upaya pencegahan dan pengobatan.

Penelitian Wijaya (2013) terdapat hubungan antara variabel pengetahuan dengan keaktifan kader $(\mathrm{p}=0,0012$ $\mathrm{OR}=18,44)$, satu antara sikap dan keaktifan kader $(p=0,0018$ OR=15,01). Faktor pengetahuan, sikap, dan motivasi kader kesehatan memegang peranan penting dalam hubungannya dengan keaktifan kader kesehatan dalam pengendalian kasus Tuberkulosis. Pemberian pelatihan kepada kader kesehatan akan mengubah perilaku kader kesehatan tentang pengetahuan, sikap dan motivasi dalam pengendalian penyakit TB paru. Kader kesehatan diberi pelatihan tentang kemandirian pada pasien TB paru, setelah itu kader akan menyampaikan kepada masyarakat terutama pada penderita TB paru, sehingga pasien tidak hanya dapat pengetahuan dari tenaga kesehatan tetapi bisa dari masyarakat sekelilingnya yang dekat dengan kader .

Penelitian Sumartini

menyebutkan ada pengaruh penguatan kader kesehatan dalam penemuan kasus TB paru melalui edukasi dengan pendekatan Theory of planned behavior terhadap angka penemuan kasus TB BTA positif. Penelitian Trisnawati(2008) menyebutkan kemampuan kader kesehatan setelah dilakukan pelatihan kader kesehatan tentang TB paru sehingga diharapkan kader kesehatan dapat menyebarkan informasi yang dimiliki pada pasien TB paru. Kader kesehatan setelah diberikan pelatihan menyebarkan informasi ke pada masyarakat terutama penderita $\mathrm{TB}$ paru dan keluarga, sehingga meningkatkan kemandirian fisiknya. Penelitian-penelitian tersebut merupakan upaya peningkatan pengetahuan kader berupa latihan dan edukasi tentang TB paru saja belum mencakup kemandirian fisik pada pasien TB paru. Pada penelitian ini dibutuhkan keahlian lebih lanjut, sehingga dibutuhkan intervensi yang dilakukan oleh kader kesehatan berupa dukungan kader kesehatan terhadap kemandirian fisik pasien TB paru.

$$
\text { Penelitian May }
$$

menyebutkan peran kader kesehatan sebagai tokoh masyarakat menimbulkan keseganan para penderita dan keluarga, yang dikatakan akan dipatuhi dari pada PMO, sehingga kader berperan sebagai daya tarik untuk menguggah emosi pasien TB paru dan meningkatkan kemandirian fisik pada kelompok intervensi setelah diberi intervensi berupa dukungan kader mempunyai rata-rata lebih tinggi. Hal ini dikarenakan adanya perlakuan dengan memberi dukungan kader kesehatan tentang TB paru. Ditinjau dari hasil kuesioner terdapat peningkatan kemandirian fisik pada pasien TB paru meliputi: membuang dahak ditempatnya, menutup mulut saat batuk, makan 3 kali sehari dengan cukup energi dan protein, membuka jendela/pintu pada pagi hari, mengambil obat ke Puskesmas sesuai anjuran petugas kesehatan, periksa dahak sesuai dengan anjuran tenaga kesehatan dan minum obat $\mathrm{TB}$ paru secara teratur sesuai program. Hasil kuesioner kemandirian fisik pasien TB paru yang tetap adalah pasien TB paru memakai masker selama berbicara dengan orang lain dan periksa ke tenaga kesehatan jika memiliki keluhan fisik berupa mual, muntah, pusing, telinga berdengung dan pandangan kabur.

Setelah diberi intervensi dukungan kader kesehatan masyarakat mulai mengerti karena mendapat informasi 
dari kader kesehatan tentang TB paru bagaimana pengertian tentang TB paru, makan dalam setiap hari, cara penularan, keteraturan dalam minum obat, mengatasi gejala jika mengalami keluhan. Kader kesehatan dalam melakukan intervensi dilakukan setiap hari, dikarenakan pasien TB paru terdapat dalam lingkup RT kader kesehatan, sehingga dalam keseharian sering untuk berkomunikasi dan juga bisa menemui keluarga pasien. Pemahaman yang telah dimiliki pasien sehingga pasien TB paru mengaplikasikan kemandirian fisik dalam kehidupan sehari-hari. Pasien sudah mulai makan setiap hari dengan cukup energi, mengerti bahaya penularan dengan memakai masker dan membuang dahak pada tempatnya Meskipun masih ada responden yang nilai kemandirian tetap. Penelitian Nugraheni (2011) menyatakan ada hubungan kejadian TB paru dengan kebiasaan tidak menutup mulut saat batuk (OR=15,3), kebiasaan membuang dahak $(\mathrm{OR}=43,529)$. Pasien dengan tidak menutup mulut jika batuk, membuang dahak tidak pada tempatnya merupakan kemandirian yang kurang, karena efek samping pada penularan pasien TB paru.

Berdasarkan penelitian Nursasi (2014) yang menyebutkan bahwa ada pengaruh peningkatan kemandirian perawatan pasien TB paru dapat dilakukan dengan pemberdayaan dalam anggota keluarga dan kelompok keluarga mandiri (KKM). Hasil penelitian menunjukkan adanya peningkatan kader dan perawat tentang TB paru setelah diberikan pelatihan berpengaruh positif pada masyarakat, sehingga masyarakat sadar akan tanda dan gejala serta bahaya dari TB paru dan masyarakat mampu mandiri untuk deteksi awal penyakit TB paru dan menghindari keparahan penyakit dan mencegah penularan ke masyarakat lain. Pengetahuan kader kesehatan meningkat setelah mendapat pelatihan tentang kemandirian fisik di salah satu Puskesmas di Indonesia. Kader kesehatan mulai menyosialisasikan kepada pasien TB paru tentang kemandirian fisik. Sehingga pasien mulai meningkat kemandirian fisik selama penjalani pengobatan TB paru.

Kelompok kontrol pada Pasien TB paru menunjukkan hasil analisis tidak ada perubahan yang signifikan tentang kemandirian fisik pada pasien TB dengan $p$-value $=-$-529.Tetapi terdapat peningkatan sedikit di rata-rata sejumlah 0,19. Hal ini mungkin disebabkan pasien TB paruada yang mendapat informasi tentang kemandirian fisik dari media elektronik seputar tentang TB paru sehingga pasien TB paru juga menjalankan pengobatan TB paru dengan mandiri.

\section{SIMPULAN}

Kemandirian fisik pasien TB paru mengalami kenaikan setelah diberi intervensi dukungan kader kesehatanpada kelompok intervensi sedangkan pada kelompok kontrol tidak mengalami kenaikan kemandirian fisik pasien TB paru.

\section{DAFTR PUSTAKA}

Al Arif D.(2015). Angka Kejadian Tuberkulosis Paru pada Pasangan Suami Istri Penderita Tuberkulosis Paru BTA Positif di Poliklinik Paru RSUD Arifin Achmad. JOM FK . 2.

Alligood MR. (2010). Nursing Theorists And Their Work. Elsevier Mosby.

Arikunto S. (2010). Prosedur Penelitian. Jakarta, Penerbit Rineka Cipta .

Bimantara G. (2016). Tuberkulosis Di Indonesia Terbanyak ke dua 
didunia.

http/print.kompas.com/baca/sai ns/kesehatan/2016/03/04.

diakses pada tanggal 12 Oktober, 2016.

Budiman. (2013). Penelitian Kesehatan. Edisi 2. Bandung. PT Refika Aditama.

Cohen S, Syme Sl. (1985). Issue in the Study and Application of Social Support. Orlando : academic

Data Puskesmas Deket. Desember ; 2016.

Dharma KK.(2011). Metodologi Penelitian Keperawatan. Jakarta, CV Trans Info media.

Dinas Kesehatan Jawa Timur. Jatim

Dalam Angka 2014

.https://www.academia.edu/700 9204/JATIM_DALAM_ANGK A_TERKINI. 2014 . Diakses tanggal 18 September ,2016.

Dwidiyanti M. (2014). Intervensi Keperawatan Holistik Program SOWAN Melalui Target Sehat mandiri pada Pasien TB paru. Prosiding Konferensi Nasional II Jawa Tengah .

Dwidiyanti M. (2014). Model Pelayanan Penyakit Kronis. Proceding Seminar Ilmiah Nasional Kperawatan"2 ${ }^{\text {nd }}$ Adult Nursing Practice: Using Evidence in care Apikasi Evidence Based Nursing dalam meningkatkan Patient Safety. Program Studi ilmu Keperawatan Fakultas Kedokteran Universitas Diponegoro .
Dwidiyanti M.( 2017). Peningkatan kemampuan pasien dalam merawat diri sebagai hasil pelayanan keperawatan.Semarang. Undip Press

Effendi F, Makhfudli. (2013). Keperawatan Kesehatan Komunitas Teori dan praktik dalam keperawatan. Jakarta, Salemba Medika

Edgeworth R. Self Care for Health in Rural Bangladesh. Doctoral Thesis Northumbria University. (2011). this versia was downloaded from northumbria research link. http// nrl.northumbria.ac.uk/1006

Galvao, Pinto ES, et al. (2016). Self Care Assisted in People with Tuberculosis Treatment. International Medical Society. 9 (135) doi: 10.3823/2006.

Hastono SP.(2007). Analisis Data. Depok. Fakultas Kesehatan Masyarakat Universitas Indonesia.

Jendra, F.J. Hubungan Faktor Risiko Umur, Jenis Kelamin dan Kepadatan Hunian dengan Kejadian Penyakit TB paru di desa Wori kecamatan Wori. Jurnal Kedokteran Komunitas dan Tropic.2015; 3(2) , April, 2015.

Kemenkes RI. (2014). Pedoman Nasional Pengendalian Tuberkulosis. Kementrian Kesehatan Republik Indonesia Direktorat Jenderal Pengendalian Penyakit dan Penyehatan Lingkungan. 
http://spritia.or.id/dokumen/ped oman-tbnasional2014 pdf. Diakses pada tanggal 10 Oktober, 2016.

Konday PP. (2014). Faktor-faktor yang Berhubungan dengan Kepatuhan Berobat Pasien Tuberkulosis Paru di lima Puskesmas di kota Manado. Jurnal kedokteran komunitas dan tropic.; 2(1) Februari 2014.

Lawn, Sharon, Schoo, Adrian et al. (2010). Review Supporting Self- Manajement of Cronic Health Condition: Common Approaches. Journal of Patient Education and Conseling 80 . 205-

211.2009.www.elsevier.com/lo cate/pateduco

Maya M. (2014). Peran Komunikasi Kesehatan pada Kalangan Masyarakat Miskin. DOI : 10 7454/mssh. V1812.xxxx 149158.

Menteri Kesehatan RI.(2011). Strategi Nasional Pengendalian TB di Indonesia 2010-2014. Jakarta. Direktorat Jenderal Pengendalian Penyakit dan penyehatan lingkungan

Muaf F. (2014). Faktor- faktor yang Mempengaruhi Kejadian Tuberkulosis Paru Basil Tahan Asam Positif di Puskesmas Wilayah Kec. Serang. Jakarta. Skripsi.

Nursasi AY. (2013). Peningkatan Kemandirian Perawatan klien TB paru melalui Pemberdayaan dalam Kelompok Keluarga Mandiri. Jakarta.

Nugraheni, D. (2011). Analisis faktor yang berhubungan dengan kejadian TB paru di Kecamatan Karangrayung Kabupaten Grobogan. Jawa Tengah. Skripsi.

Trisnawati. (2008). Pelatihan Peningkatan Kemampuan Kader Kesehatan Dalam Penanganan Tuberkulosis (TBC) di wilayah Kerja Puskesmas Gemolong II Sragen. Warta. 2008 ; 11(2) :150-158. September.

Nooratri ED.(2016). Faktor yang Mempengaruhi Efikasi Diri pada Pasien TB paru. Jurnal of Nursing and Health Jurnal Keperawatan Akper Yakpermas- Banyumas. 2015 ; 2(1) : 24-28. Agustus.

Nooratri ED.(2016). Peningkatan Efikasi dan Kemandirian fisik pada Pasien Tuberkulosis Paru Melalui Intervensi Mindfulness dibalai Kesehatan Paru Masyarakat Magelang. Tesis. Program Studi Magister Keperawatan Fakultas Kedokteran Universitas Diponegoro.

Notoatmojo S.(2010). Metodologi Penelitian Kesehatan. Jakarta, PT. Rineke Cipta .

NSW Department of Health. (2008). Chronic Disease SelfManagement Support. Australian Resource Centre for Healthcare Innovations (ARCHI) .

Nursalam. (2015).Konsep dan Penerapan Metodologi Penelitian Ilmu Keperawatan. Jakarta, Salemba Medika. 
Nugraheni, D.(2011). Analisis Beberapa

Faktor yang Berhubungan dengan Kejadian TB paru di Kecamatan Karangrayung Kabupaten Grobogan. Skripsi; 2011.

Orem DE. (2001). Nursing Oncepst of Practice. The CV Mosby Company, St Louis.

Pratiwi NL. (2012). Kemandirian Masyarakat dalam Pencegahan Penularan Penyakit TB paru. Buletin Penelitian Sistem Kesehatan. 2012; 15(2) : 162169. April.

Retni A. (2010). Hubungan Dukungan Sosial Keluarga dengan Tingkat Kesembuhan Penderita TB paru di Puskesmas Umbulharjo IIYogyakarta.

Sodhi S, Banda H, Kathyola D, et all.(2014). Supporting middlecadre health care worker in Malawi: lessons learned during implementation of the PALM PLUS package. Health Services Research;14 (Suppl 1):S8. http://www.biomedcentral.com/ bmchealthservres/content/14/SI/ $\underline{\text { S8. }}$.

Sumartini NP.(2013). Penguatan Peran Kader Kesehatan dalam Penemuan Kasus Tuberkulosis (TB) BTA Positif Melalui Edukasi dengan Pendekatan Theory of Planned Behaviour (TPB) .

Sugiyono. (2016). Metodologi Penelitian Kuantitatif Kualitatif dan R\&D. Bandung, Alfabeta.

Trisnawati. (2008). Pelatihan Peningkatan Kemampuan Kader Kesehatan Dalam
Penanganan Tuberkulosis (TBC) di wilayah Kerja Puskesmas Gemolong II Sragen. Warta. 2008 ; 11(2) :150-158. September.

Venkatrajul B, Prasad S. Psychososial Trauma of Diagnosis.(2013). A qualitative Study on Rural TB Patiens Experiences in Nalgonda District Andhira Pradesh. Indian J Tuberculosis.

Wijaya MK. (2013). Pengetahuan, Sikap, dan Motivasi terhadap Keaktifan Kader dalam Pengendalian Tuberkulosis. Jurnal Kesehatan Masyarakat KEMAS. 2013;8 (2): 137-144. 